\title{
BAHAYA DARI TIDUR TERLALU LAMA BAGI
}

KESEHATAN

\author{
Nama:Laila Yolanda Putri Aryanti \\ Nim :2161B0034
}

lailayolanda@gmail.com

\begin{abstract}
Abstrak
Bisa di Katakan Bahwa Sesuatu yang di Lakukan dengan Betlebihan tidak baik untuk Kesehatan Termasuk dengan Tidur dalam Waktu yang terlalu Lama.Tiap Orang Memiliki Kebutuhan tidur yang tidak Sama,Tergantung dari Kebiasaan yang di Lakukan Setiap Hari,Usia,Gaya Hidup dan kondisi Kesehatan Secara Keseluruhan.Kebutuhan Tidur Orang Dewasa yaitu Sekitar 7-9 Jam dalam setiap Harinya, sedangkan bagi Lansia (Lanjut Usia) biasanya Memiliki Kebutuhan Tidur Sekitar 7-8 jam perhari.
\end{abstract}

\section{Latar Belakang}

Anda mungkin termasuk Satu dari Sekian banyak Orang yang begitu Menikmati waktu tidur Berbaring di atas tempat tidur yang nyaman Sepanjang hari Sungguh Nikmat,daripada Melakukan aktivitas lain yang Melelahkan.Namun,Melakukan hal itu justru dapat Berbahaya. Secara umum tidur adalah cara terbaik untuk Memulihkan Kondisi tubuh agar Kembali Sehat dan bugar.Namun, bukan berarti kamu boleh tidur Seharian tanpa Melakukan aktivitas yang lain.Sama hal nya dengan kurang tidur,tidur berlebihan juga tidak baik untuk Kesehatan.Oleh sebab itu, hal yang terbaik adalah Tidur Cukup sesuai Porsi.

\section{Kasus/Masalah}

- Bahaya apa saja yang timbul bagi kesehatan jika tidur terlalu lama ?

Tidur terlalu lama bisa Menimbulkan Bahaya bagi Kesehatan, di antaranya:

a).Mengalami Sakit Kepala

pernah anda tidur lebih dari 12 jam lamanya ? Hal tersebut bisa Menyebabkan Otak Seolah berembun dan timbul Sakit Kepala.ya,kondisi ini bisa menjadi salah satu bahaya yang mungkin anda alami jika tidur terlalu lama. 
b).Menyebabkan rasa Sakit pada Sekujur tubuh

Salah satu Bahaya yang mungkin anda alami saat tidur terlalu lama adalah Sekujur tubuh yang terasa sakit. Kondisi ini bisa saja terjadi karna saat tidur anda melakukan banyak gerakan.

c).Meningkatkan resiko diabetes dan penyakit jantung

Salah satu bahaya yang anda mungkin anda alami saat tidur terlalu lama adalah meningkatkan Risiko mengalami diabetes. Kondisi ini bisa terjadi saat anda kurang tidur maupun terlalu lama Tidur.Oleh sebab itu,penting sekali untuk mengatur siklus tidur Anda.

d).Meningkatkan risiko obesitas

Terlalu banyak tidur ternyata juga bisa menimbulkan bahaya terhadap berat badan Anda.

Pasalnya,kebiasaan tak sehat ini juga berpotensi menyebabkan kenaikan berat badan hingga Obesitas.Secara logika,saat terlalu banyak tidur tubuh menjadi jarang bergerak apalagi berolah Raga.

Hal tersebut menyebabkan risiko mengalami obesitas semakin meningkat.Bahkan meski masih rutin berolahraga,Anda masih rentan mengalami kenaikan berat badan jika terlalu banyak tidur menurut para ahli,ada penyebab lain yang mungkin bisa memicu hal tersebut terjadi.

e).Meningkatkan risiko stroke

Selain penyakit jantung,Stoke juga merupakan salah satu bahaya yang mungkin anda alami jika Tidur terlalu lama.Bahkan,kurang tidur juga bisa menyebabkan Anda mengalami kondisi ini. Hal Ini juga telah dibuktikan oleh sebuah penelitian pada tahun 2017.

Menurut penelitian tersebut,durasi tidur sangat berpengaruh terhada risiko stroke. Oleh sebab itu Baik kurang tidur maupun tidur secara berlebihan sama-sama meningkatkan kesempatan Anda Mengalami salah satu penyakit mematikan ini.

\section{f).Mengganggu Kesuburan}

Baik pada wanita maupun pria,terlalu banyak tidur dapat mengganggu Kesuburan. Hal ini tentu Menjadi salah satu bahaya tidur terlalu lama yang mengkin Anda alami.Sama halnya dengan Kurang tidur,kondisi ini juga dapat memengaruhi kadar hormon dalam tubuh. 
Sementara itu,kadar hormon sangat berkaitan erat dengan kesuburan.Oleh sebab itu,jika Anda

Tidak ingin kesuburan terganggu,lebih baik terapkan kebiasaan tidur yang sehat jangan tidur Secara berlebihan.

g).Mengalami depresi

Ternyata,orang yang tidur terlalu lama bisa mengalami masalah pada kesehatan mentalnya.

Ya,ternyata salah satu bahaya tidur terlalu lama adalah gangguan pada kesehatan mental,salah Satunya depresi.Namun,kondisi ini masih cukup membingungkan bagi para ahli.

Pasalnya para ahli masih belum bisa menentukan apakah kebiasaan tidur terlalu lama ini terjadi Akibat depresi,atau sebaiknya? Yang jelas kedua hal ini saling terkait.Ini tandanya,jika anda tidur Lama,kemungkinan mengaalmi depresi pun akan semakin besar.

\section{Tinjauan Pustaka}

Tidur merupakan Kebutuhan bagi tubuh,sama seperti hal nya dengan Makan dan Minum.Akan tetapi tidur terlalu lama bisa menimbulkan bahaya bagi Kesehatan di antaranya mengalami Sakit di bagian Kepala tubuh anda tidak mendapatkan Cairan hingga 12 jam lebih.itu sebabnya,anda bisa saja mengalami dehidrasi selama tidur dan bangun dalam Kondisi Kepala terasa Sakit akibat kekurangan Cairan.

\section{Pembahasan}

Banyak Orang beranggapan bahwa tidur lama bisa menghilangkan rasa lelah.Namun,sebaliknya tidur terlalu lama Justru bisa membuat kita merasa kurang berenergi.Selain itu,ada beberapa Bahaya tidur terlalu lama yang juga perlu diperhatikan, misalnya peningkatan risiko munculnya Penyakit tertentu.

Untuk mendapatkan manfaat tidur yang sesungguhnya,Anda harus memperbaiki kualitas tidur anda Terlebih dahulu tidur yang berkualitas belum tentu tidur yang lama dan sebaliknya,tidur yang terlalu Lama belum tentu berkualitas.

Dibawah ini adalah beberapa cara yang bisa dilakukan untuk memperbaiki kualitas tidur Anda,sehingga terhindar dari bahaya tidur terlalu lama.

\section{Buat jadwal tidur}


Untuk memastikan Anda tidur tepat waktu buatlah jadwal tidur dengan menentukan jam tidur Malam dan jam bangun. Hindari berbagai hal yang membuat Anda terjaga atau sulit tidur pada Malam hari,misalnya mengkonsumsi minuman berkafein dan tidur siang terlalu lama.

\section{Olahraga secara rutin}

Olahraga ternyata tidak hanya baik untuk kesehatan tubuh,namun juga dapat membantu Anda Memperbaiki pola tidur.Akan tetapi,hindari olahraga sesaat sebelum tidur,karna olahraga dapat Memicu produksi hormon adrenalin dan detak jantung meningkat. Hal ini justru bisa membuat Anda Sulit tidur.

\section{Kesimpulan}

Setiap Orang memiliki Kebutuhan tidur yang berbeda-beda,tergantung Usia,aktivitas, sehari hari,gaya hidup,dan Kondisi Kesehatan. Waktu tidur ideal untuk orang dewasa berkisar 7-9 jam,sedangkan Lansa (Lanjut Usia) membutuhkan waktu tidur sekitar7-8 jam.

Anda perlu mencukupi waktu tidur dan biasakan untuk tidak kurang tidur atau tidur berlebihan karna gangguan tidur tersebut bisa menimbulkan berbagai masalah Kesehatan.

\section{Daftar pustaka}

Atkinson \& Hilgard,Edward E. Smith dkk. 2006. Introduction to Psychology.14 th Edition USA.Thomson, Wadsworth,

Banks, S., \& Dinges, D.F. 2007.Behavioral and physiological consequences of sleep Restriction.journal of clinical sleep.Medicine,3(5),519-528

Pola tidur sehat Hapsari,annisa ,2021. Adrian,kevin,2020. 